\title{
HUBUNGAN ANTARA LABA PERUSAHAAN DAN KOMPENSASI CEO DENGAN MENGGUNAKAN DATA PANEL
}

\author{
Tiarapuspa \\ Universita s Trisa kti J a karta
}

\begin{abstract}
The main purpose of this research is to explain the relationship between profit and CEO compensation. The relationship between CEO compensation and company profit in 1992-1996 from 32 fims that listed in J aka rta Stock Exchange has a different result. Some researches find that there is a significant relationship but in the other hand find there isn't a significant relationship. This result support generalization or validity extemal from previous research. This research used panel data to exa mination this relationship.
\end{abstract}

Keywords: profit, CEO Compensation

\section{PENDAHULUAN}

\section{Latar Belakang}

Data mengenai peringkat gaji sesuai dengan profesinya menunjukkan bahwa Chief Executife officers, dari perusahaan yang besar umumnya menempati urutan rating gaji yang tertinggi (Wade and Porak 2006). Kompensasi dari CEO sering diknitik tidak berhubungan dengan laba perusahaan, kompensasi dari CEO juga sering dinyatakan hanya berhubungan dengan orientasi jangka pendek dibandingkan profit jangka panjang, (Deckop 1988). Menurut Deckop (1988) bukti yang mendukung mengenai kritik tersebut diatas banyak yang bersifatnya subyektif, sebagai contoh laporan bisnis memaparkan peningkatan gaji dari CEO meskipun kineja perusahaan mengalami penurunan. Bagaimana dengan bukti objektif? Para ahli di bidang studi mengenai kompensasi menyatakan prediktor terbaik untuk kompensasi CEO adalah firm size, studi empirik yang dilakukan oleh Roberts (1959) dan McGuire, Chiu dan Elbing (1962) dikutip dari Deckop (1988) mendorong usulan bahwa kompensasi dari CEO banyak berhubungan dengan zise perusahaan. Size perusahaan diproksi dengan menggunakan sales. Hubungan yang kuat antara kompensasi dengan sales mengusulkan bahwa CEO diberikan insentive untuk memaksimalkan size, dengan logika demikian maka hal ini justru bertolak belakang dengan kepentingan dari pemegang saham. Efek kompensasi yang didasarkan pada sales ini menjadikan adanya pemisahan antara kepentingan pemilik dengan peran CEO sebagai wakil yang dipilih oleh pemilik untuk mengontrol kegiatan manajer dalam perusahaan. 
Pada tahun 1970 Lewellen dan Hunstman mendapatkan suatu solusi yang bertolak belakang dengan penelitian sebelumnya, menemukan adanya bukti positif yang signifikan antara profit atau laba dengan kompensasi dan tidak ada hubungan antara sales dengan kompensasi. Hasil yang tidak sama dengan penelitian yang sebelumnya (sales dan kompensasi) mengakibatkan banyak studi yang dilakukan untuk meneliti hubungan antara profit dan kompensasi, namun hasil akhir dan debat yang muncul masih simpang siur. Maka tujuan dari studi ini adalah mengetahui bagaimana pengaruh profit dengan kompensasi CEO dengan latar belakang sampel perusahaan yang ada di Indonesia. Jika hasil penelitian sebelumnya banyak dilakukan dengan mengambil sampel perusahaan di negara barat, maka studi ini justru ingin mengetahui apakah hubungan yang positif dan signifikan yang ditemukan antara profit dan kompensasi eksekutif juga berlaku di setting negara yang berbeda.

\section{Pemasalahan}

Permasalahan dalam studi ini adalah untuk melihat bagaimana hubungan profit terhadap kompensasi yang diterima oleh CEO dengan studi empirik pada perusahaan-perusahaan yang terdaftar di Bursa efek Jakarta pada tahun 1992 1996.

\section{LANDASAN TEOR}

CEO merupakan wakil dari para pemilik perusahaan atau Board of Director yang memonitor kineja manajemen pada perusahaan yang sudah go publik, meningkatnya profit atau laba bersih sesudah pajak (yaitu selisih antara pendapatan atau penjualan dengan biaya yang dikeluarkan untuk melakukan aktivitas) menunjukkan kemampuan CEO untuk mengontrol manajer melakukan suatu aktivitas yang dapat meningkatkan nilai perusahaan, dan hal ini tentunya menjadi suatu keuntungan bagi para stakeholder perusahaan tersebut. Keberhasilan CEO tersebut sudah sepantasnya dihargai dengan memberikan kompensasi bagi CEO, Iskandar (1999). J a di dalam hal ini va riabel profit seperti telah diuji pada penelitian sebelumnya, seperti Roberts (1959) dan McGuire, Chiu dan Elbing (1962) memang memiliki hubungan positif dan signifikan dengan kompensasi CEO.

Kompensasi dari CEO juga bervariasi tergantung dari pengaruh pasar intemal dan ekstemal. Sebagai contoh asal perekrutan CEO. CEO yang direknut dari luar perusahaan mensyaratkan suatu pembayaran premium dalam hal insentif, sementara CEO yang direkrut dari intemal biasanya akan menerima pembayaran yang relatif kurang untuk status dan kebanggaan yang dihubungkan dengan promosi yang diperolehnya. Kelompok CEO yang ketiga adalah mereka yang memperoleh posisi disebabkan karena perananannya sebagai pendin perusahaan. 
Bagaimana peranan extemal labor market dalam mempengaruhi kompensasi CEO, pera na n ini biasanya dihubungkan dengan index. Index hasil survey mengenai kompenasi yang dikumpulkan oleh komite Board of Director akan digunakan sebagai dasa r penga mbilan keputusan untuk kompensasi.

Menurut Bacon (1982) dikutip dari Deckop ( 1988), bahwa ada index umum yang digunakan untuk pembayaran executive pada industri yang sama. Penjelasan penggunaan index tersebut (1) adanya kondisi ekonomi yang sifa tnya eksogen dan legal development seperti resesi dan deregulasi, biasanya akan berpenga ruh pada semua perusahaan dibandingkan hanya satu perusahaan tertentu dalam sebuah industri. Kinerja perusahaan la in dalam satu industri dapat digunakan untuk menilai kinerja perusahaan lain dalam industri yang sama. (2) perusahaan dalam industri yang sama akan lebih dapat mewakili dibandingkan penusahaan dalam industri yang berbeda dalam hal peluang bekeja sebagai CEO di tempat lain. Seorang CEO yang dibayar dibawah standar/underpaid akan mungkin berpindah apabila menemui suatu kemungkinan. Pertimbangan extemal market tersebut mendasari adanya segmentasi sepanjang industri . Jadi industri dapat dipakai sebagai suatu ramalan atau proksi dari ekstemal labor market. Apabila industri berpengaruh secara langsung, maka hal ini akan bemengaruh pada intercept term dalam model rerangka regresi, selanjutnya industri a kan mempengaruhi kompensasi CEO akan ditransmisikan langsung melalui slope dari satu atau lebih variabel independent. Slope dari variabel kinerja organisasi (profit) akan bervariasi antara industri, karena variabel tersebut menupakan proxy legal dari faktor ekonomi yang mempenga ruhi industri secara keseluruhan, Deckop (1988).

\section{METODE PENEUTIAN}

\section{Data}

Untuk menguji hipotesis dikumpulkan data panel selama 5 tahun dari tahun 1992 dan berakhir tahun 1996. Da lam studi ini akan dilakukan analisa data kompensasi CEO dari 32 pensahaan dari 2 industri yaitu manufaktur dan jasa. Waktu pengamatan dipilih dengan alasan pada tahun 1997 telah terjadi krisis moneter, sehingga perolehan data sekunder mulai tahun 1997 tidak selengkap data tahun sebelum 1997, da ta dikumpul mulai tahun 1992 dengan a lasan pada tahun ini mulai terdapat pelaporan yang lengkap mengenai kompensasi dari CEO,maka data sekunder yang diambil adalah mulai ta hun 1992 sampai 1996.

Adapun data mengenai kompensasi didefinisikan sebagai salary yang diberikan kepada CEO ditambah dengan bonus selama satu tahun dalam juta rupiah, datanya diperoleh dari majalah warta ekonomi, sedangkan la ba selama satu tahun fiskal yaitu berupa net income dari perusahaan, dalam juta rupiah, diperoleh dari majalah warta ekonomi. Industri digunakan sebagai dummy variabel, dikelompokkan sebagai 1 ya itu ind ustri ma nufa ktur dan 0 sebaga i ind ustri jasa. 


\section{Metode dan Model}

Kebanyakan studi terdahulu mengenai kompensasi CEO dilakukan dengan cara cross section, dan kurang menggunakan analisis pengamatan longitudinal. Dalam studi ini digunakan data panel yang merupakan gabungan cross section dan time series yang selanjutnya untuk pengujiannya dilakukan dengan bantuan program eviews versi 3 (Insukindro, Ma ryatmo, Aliman, 2001).

Adapun model dari data panel penelitian ini adalah :

Kit $=\beta 1+\beta 2$. L2it

Dimana:

K=kompensasi

$\mathrm{L}=\mathrm{Laba}$

$\mathrm{i}=1,2, \ldots, 32$ perusahaan

$\mathrm{t}=1,2,3,4,5$ tahun

$\beta 1=$ intercept $\quad \beta 2=$ Koefisien

Ka rena cross sectional unit memiliki jumlah yang sama dengan observasi time series nya, maka panel data dalam penelitian ini dikatagorikan sebagai balance panel. Dalam panel data ini diasumsikan pula bahwa variabel independent adalah non stokastik dan emor term nya mengikuti asumsi klasik (Verbeek, 2004). Sela njutnya model persamaan dalam penelitian ini akan diestimasi, adapun estimasi yang dibuat akan tergantung dari asumsi terhadap intercept, slope koefisien, dan error term, terdapat beberapa kemungkinan model yang dikembangkan.

\section{Model 1}

Mengasumsikan bahwa intercept dan slope koefisien adalah konstan sepanjang waktu dan tempat dan error term meliputi perbedaan waktu dan perusahaan.

Kit $=\beta 1+\beta 2$. L2it

\section{Model 2}

Mengasumsikan bahwa sope koefisien adalah konstan namun intercept bervariasi pada tiap perusahaan.

$K t=\sum \beta 1+\beta 2 . L 2$ it $+\mu$ it 
Model 2 yang digunakan pada persamaan (3) adalah Fixed effect model ( FEM), artinya bahwa meskipun intercept-nya berbeda pada masing-masing perusahaan namun namun slope koefisiennya tetap konstan tiap perusahaan. Hal ini disebut sebagai time invariant.

\section{Model 3}

Mengasumsikan bahwa slope koefisien adalah bervariasi pada setiap perusahaan dan intercept konstan.

$K i t=\beta 1+\sum \beta 2 \cdot \mathbf{L i}+\mu i t$

\section{Model 4}

Mengasumsikan bahwa slope koefisien dan intercept bervariasi pada setiap perusahaan.

$$
\text { Kit }=\sum \beta 1+\sum \beta 2 \cdot 2 \mathbf{i}+\mu \mathrm{it}
$$

Dalam studi ini hanya a kan digunakan dumy berdasarkan ind ustri saja. Dumy industri tidak dimasukkan dalam model time series karena efek control dari perusahaan untuk varias terhadap keanggotan dalam industri, ketika anggota industri konstan bagi semua perusahaan sela ma perioda studi.

Untuk memilih model mana yang terbaik maka digunakan restric ted $\mathrm{F}$ test (Guja rati, 2003), dengan formula:

$$
F=\frac{\left(R^{2} u r-R^{2} r\right) / m}{\left(1-R^{2} u r\right) / n-k}
$$

Dimana:

$\mathrm{R}^{2} \mathrm{ur}=$ model yang tidak direstriksi

$\mathrm{R}^{2} \mathrm{r}=$ model yang direstriksi

$\mathrm{m}=$ jumlah restriksi linea $\mathrm{r}$

$\mathrm{k}=$ =jumlah parameter pada regresi yang tidak direstriks

$\mathrm{n} \quad$ =jumlah observasi

Adapun ketentuannya jika $\mathrm{F}$ hitung (probabila 0,05 ) $>\mathrm{F}$ tabel maka model restriksi di tolak dan yang terpilih adalah model yang tidak direstriksi. 


\section{HASIL}

Model 1:

$$
\begin{aligned}
& \text { Kit }=\boldsymbol{\beta} 1+\boldsymbol{\beta} 2 . \text { L2it } \\
& K=503,4709+0,001534 \mathrm{~L} 2 \\
& \mathrm{se}=(26,61364)+(0,000230) \\
& \mathrm{t}=(18,91778)+(6,681268 \\
& \mathrm{R}^{2}=0,220290 \text { Durbin Watson }=1,099324 \\
& n=160 \text { df }=160-2=148
\end{aligned}
$$

Model 2:

$$
K i t=\sum \beta 1+\beta 2 . L 2 i t+\mu i t
$$

$K=438,1763+629,1385+\ldots+379,1266+0,001582 \mathrm{~L} 2$

$\mathrm{R}^{2}=0,572649$ Durbin Watson $=2,002927$

Restricted Ftest ( model 1 dan model 2 )

$$
\begin{aligned}
& F=\frac{\left(R^{2} u r-R^{2} r\right) / m}{\left(1-R^{2} u r\right) / n-k} \\
& F=\frac{(0,572649-0,220290) / 31}{(1-0,672649) / 160-(32+1)}
\end{aligned}
$$

F tabel 0,05 ( 31;127) $=1,55$

Kesimpulan: F hitung > F tabel, ja di model yang digunakan adalah model 2 .

Model 3

$$
\begin{aligned}
& \mathbf{K i t}=\boldsymbol{\beta 1}+\Sigma \boldsymbol{\beta} \mathbf{2} \cdot \mathbf{L} \mathbf{i}+\boldsymbol{\mu i t} \\
& K=441,9083+0,000888 \mathrm{~L} 21+0,025213 \mathrm{~L} 22 \ldots-0,000202 \mathrm{~L} 2.32 \\
& \mathrm{se}=(37,3361)+(0,004369)+(0,006571) \quad \ldots-(0,006571) \\
& R^{2}=0,581729 \quad \text { Durbin Watson }=1,975607
\end{aligned}
$$

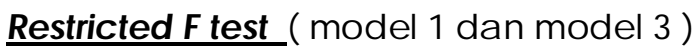


$\mathrm{R}^{2} \mathrm{ur}=$ model 3

$\mathrm{R}^{2} \mathrm{r}=$ model 1

$$
\begin{aligned}
& F=\frac{\left(R^{2} u r-R^{2} r\right) / m}{\left(1-R^{2} u r\right) / n-k} \\
& F=\frac{(0,581729-0,220290) / 31}{(1-0,581729) / 160-(32+1)}=0,0117
\end{aligned}
$$

F tabel 0,05 (31;127) $=1,55$

Kesimpulan: $\mathrm{F}$ hitung $>\mathrm{F}$ tabel, jadi model yang digunakan adalah model.

Model 4

$$
K i t=\sum \beta 1+\sum \beta 2.12 i+\mu i t
$$

$\mathrm{K}=478,8067+545,8114+793,8114+\ldots+306,6010-$ 0,000470 L2.1+0,01430L2.2+0,000848L2.3+...+306,6010 L2.32

$\mathrm{R}^{2}=0,743157 \quad$ Durbin Watson $=2,847650$

Restricted Ftest ( model 1 dan model 4 )

$\mathrm{R}^{2} \mathrm{ur}=$ model 4

$\mathrm{R}^{2} \mathrm{r}=$ model 1

$$
\begin{aligned}
& F=\frac{\left(R^{2} u r-R^{2} r\right) / m}{\left(1-R^{2} u r\right) / n-k} \\
& F=\frac{(0,743157-0,220290) / 62}{(1-0,743157) / 160-(62+2)}=3,15205
\end{aligned}
$$

F tabel $0,05(62 ; 96)=1,53$

Kesimpulan: $\mathrm{F}$ hitung $>\mathrm{F}$ ta bel, jadi model yang digunakan adala $\mathrm{h}$ model 4 .

Restricted Ftest ( model 2 dan model 4 )

$\mathrm{R}^{2} \mathrm{ur}=$ model 4

$\mathrm{R}^{2} \mathrm{r}=$ model 2 


$$
\begin{aligned}
& F=\frac{\left(R^{2} u r-R^{2} r\right) / m}{\left(1-R^{2} u r\right) / n-k} \\
& F=\frac{(0,743157-0,572649) / 31}{(1-0,743157) / 160-(62+2)}=2,05576
\end{aligned}
$$

F tabel $0,05(31 ; 96)=1,65$

Kesimpulan: F hitung > F tabel, jadi model yang digunakan adalah model 4 .

Restricted Ftest ( model 3 dan model 4 )

$\mathrm{R}^{2} \mathrm{ur}=$ model 4

$\mathrm{R}^{2} \mathrm{r}=$ model 3

$$
\begin{aligned}
& F=\frac{\left(R^{2} u r-R^{2} r\right) / m}{\left(1-R^{2} u r\right) / n-k} \\
& F=\frac{(0,743157-0,581729) / 31}{(1-0,743157) / 160-(62+2)}=1,9465
\end{aligned}
$$

F tabel 0,05 (31;96) $=1,65$

Kesimpulan: F hitung >F ta bel, jadi model yang digunakan a dala h model 4 .

Berdasarkan uji dengan Restricted $\mathrm{F}$ test maka setelah diperbandingkan maka model yang unggul adalah model 4.

\section{ANAUSA}

Model 1 yaitu mengestimasi model dengan asumsi konstanta dan intercept konstan untuk ke 32 perusahaan, model pertama sangat sederhana karena menggambarkan hubungan yang sebenamya antara kompensasi CEO dengan laba pada 32 penusahaan. Model ini kemudian dikembangkan dengan model lainnya agar lebih dapat dilihat secara spesifik bagaimana kondisi kompensasi dan provit dari ke 32 perusahaan.

Dengan menggunakan uji restricted $\mathrm{F}$ maka ketika model 1 direstriksi dibandingkan dengan model 2 yang tidak direstriksi, temyata model 2 terpilih, ka rena $\mathrm{F}$ hitung $>\mathrm{F}$ tabel. Pada model 2 intercept bervariasi antar 32 perusahaan namun slope koefisennya masih diasumsikan konstan antar perusahaan. Perbedaan intercept antar 32 perusahaan tersebut dapat disebabkan karena adanya perbedaan 
intemal perusahaan, tipe atau style managerial, yang tidak diteliti lebih lanjut dalam studi ini. Untuk model 2 ini waktu dianggap sebagai time invariant, karena hanya membandingkan perbedaan antara jenis industrinya saja. Agar intercept dapat bervariasi maka dimasukkan dummy variabel, dalam hal ini yang menjadi dummy adalah industri ya itu bila manufaktur 1 dan jasa 0 , namun karena adanya near singular matrix ketika dimasukkan dummy variabel pada program eviews, ini berarti bahwa perusahaan dalam sampel juga sudah mengelompok dan menceminkan industri nya, sehingga ketika dimasukkan dummy akan muncul near singular matrix, maka dengan tidak memasukkan dumy pun pada model yang kedua sudah mencerminkan perbedaan variasi dari intercept masing-masing perusahaan.

Dengan menggunakan restricted $\mathrm{F}$ test juga dibandingkan model mana yang terbaik antara model 1 dan model 3. Namun antara model 2 dan model 3 memang tidak dibandingkan dengan alasan bahwa kedua model tersebut memiliki kesamaan dalam hal yang koefisien dan slope intercept yang tidak direstriksi. Dari hasil perbandingan antara model 1 dan model 3 temyata $F$ hitung dari model 1 yang direstriksi lebih besar dari $\mathrm{F}$ tabel maka dipilih model 3. Jadi untuk sementa ra model 2 dan model 3 sama- sama lebih baik dari model 1.

Untuk model 3 maka koefisien dari 32 penusahaan bervariasi sementara slope intercept-nya konstan. Selanjutnya model 2 dan model 3 dibandingkan dengan model 4 , temyata dari hasil perbandingan dengan menggunakan restricted $\mathrm{F}$ test model 4 lebih unggul dibandingkan model 2 dan 3, jadi model 4 dipilih sebagai model untuk menerangkan hubungan antara kompensa si CEO dengan laba.

Dari model 4 dapat diuraikan bahwa hubungan antara laba dengan kompensasi CEO berbeda-beda untuk ke 32 perusahaan, dan hasil hubungan yang signifikan dari model 4 nampak pada perusahaan no. 4 ( Bank Intemasional Indonesia), no. 5 ( Bank Bali ), no. 18 (Indah Kiat Paper), no. 23 (Lipo life), no. 24 (Mayora) dan no. 26 (Multi Bintang). Dari ke 6 penusahaan yang menunjukkan hubungan yang signifikan tersebut 3 perusahaan berasal dari industri jasa yaitu Bank Intema sional Indonesia, Bank Bali dan Lipo Life, dan 3 lainnya dari industri manufaktur.

Adanya kebijakan pemerintah sehubungan dengan kemudahan membuka perusahaan yang bergerak pada jasa perbankan merupakan salah satu hal ekstemal yang mempengaruhi hubungan signifikan antara laba dan kompensasi CEO. Kelemahan dari penelitian ini adalah tidak menggunakan variabel independent lain yang berkaitan dengan kineja intemal perusahaan seperti misalnya sales (sebagai proksi dari size penusahaan), memasukkan sales sebagai salah satu independent variabel dapat meningkatkan ekstemal validity dari penelitian sebelumnya mengenai pendapat bahwa tidak ada hubungan antara sales dan kompensasi CEO pada setting negara yang berbeda.Kelemahan yang lain adalah tidak digunakannya dumy tahun untuk membandingkan bagaimana perbedaan kompensasi CEO dan laba, mungkin tahun 1996 bisa dijadikan sebagai 
patokan dumy, mengingat pada tahun 1996 sudah mendekati tahun 1997 yang pada sa at itu terjadi krisis moneter.

\section{KESIMPULAN}

Hubungan antara kompensasi CEO dengan laba perusahaan pada tahun 19921996 dengan sampel 32 perusahaan yang terdaftar di Bursa Efek Jakarta, menunjukkan hasil yang berbeda-beda diantara 32 perusahaan tersebut, yaitu ada yang menunjukkan hubungan yang signifikan maupun ada yang tidak signifikan. Hal ini menguatkan generalisasi a ta u ekstemal validity dari penelitian sebelumnya yang banyak dilakukan di negara Barat yang hasilnya juga masih simpang siur karena, bahwa di Indonesia-pun dalam hal ini perusahaan di Jakarta menunjukkan hubungan yang berbeda-beda antarperusahaan.

Untuk penelitian mendatang disarankan menambahkan variabel nilai saham perusahaan yang dapat mencerminkan kineja jangka panjang perusahaan, selain itu faktor intemal seperti sumber rekrutmen CEO, pengalaman dari CEO, ma sa keja juga dapat menjadi variabel independent lain untuk melihat hubungan antara kinerja perusahaan dengan kompesasi CEO.

\section{DAFTAR REFERENSI}

Deckon,J.R., 1988, Determina nts of Chief Executive Offic er Compensation .Ind ustrial and Labor Relations Review. Vol.41: 2.

Gujarati, D.N., 1995, Basic Econometric, McGraw Hill, Inc.

Insukindro, Maryatmo, Aliman., 2001, Modul Ekonometrika Dasar dan Penyusunan Ind ika tor Ung gula n Ekonomi.

Iskandar, M., Mayerman.G.,et al ., 1999, Corporate Restructuring and Govemance in East Asia. Finance \& Development, Mar, 36.

Verbeek, M., 2004, A guide to Modem Econometrics, second edition, J ohn Wiley \& Sonsitd.

Wade,J.B., and Porac J.F., 2006, The Burden of Celebrity the Impact of CEO Certification Contest on CEO Pay \& Performance. Academy of Management J oumal. Vol.49(4): 646-660.

Majalah Warta Ekonomi , 1997, 03,XXII,9-22 Februari: 32-45. 